COSTA, Luís Otávio Monteiro; FABRIZ, Daury Cesar. Deveres fundamentais e soberania popular: a desobediência civil como mecanismo de participação democrática e promoção de direitos fundamentais. Revista Eletrônica Direito e Política, Programa de Pós-Graduação Stricto Sensu em Ciência Jurídica da UNIVALI, Itajaí, v.13, n.1, $1^{0}$ quadrimestre de 2018. Disponível em: www.univali.br/direitoepolitica - ISSN 1980-7791

\title{
DEVERES FUNDAMENTAIS E SOBERANIA POPULAR: A DESOBEDIÊNCIA CIVIL COMO MECANISMO DE PARTICIPAÇÃO DEMOCRÁTICA E PROMOÇÃO DE DIREITOS FUNDAMENTAIS
}

\author{
FUNDAMENTAL DUTIES AND POPULAR SOVEREIGNTY: THE CIVIL DISOBEDIENCE \\ AS A MECHANISM OF DEMOCRATIC PARTICIPATION AND PROMOTION OF \\ FUNDAMENTAL RIGHTS
}

\section{Luís Otávio Monteiro Costa ${ }^{1}$ \\ Daury Cesar Fabriz²}

SUMÁRIO: Introdução; 1. Estado Democrático, soberania e participação popular nas ações políticas; 2 . O dever geral de obediência às leis e a desobediência civil nas perspectivas de Garcia, Thoreau, Walzer e Dworkin; 3. O dever de desobediência civil à luz do regime jurídico dos deveres fundamentais; Considerações finais; Referências das fontes citadas.

\section{RESUMO}

O artigo objetiva analisar a desobediência civil como um instrumento útil para fins de exercício da democracia direta nos casos em que se vislumbre a edição de leis injustas ou que violem direitos. Argumenta-se que, diante da ineficiência no emprego de mecanismos de democracia direta e da patente crise de legitimidade dos representantes, o povo brasileiro se encontra distanciado das tensões políticas que fundamentam a criação de leis e medidas por parte do governo, sendo a desobediência uma forma não institucionalizada, porém eficaz, de manifestação política contra leis injustas. Ademais, buscar-se-á demonstrar que, para além de um direito fundamental ou um dever moral, a desobediência civil, à luz do princípio republicano e democrático, pode ser compreendida com um dever fundamental a ser praticado em situações em que a lei ou medida governamental considerada injusta reprima direitos fixados no ordenamento jurídico.

Palavras-chave: Soberania popular; Desobediência civil; Deveres fundamentais

1 Mestrando do Programa de Pós-Graduação Stricto sensu em Direitos e Garantias Fundamentais pela Faculdade de Direito de Vitória (FDV). Pós-graduado em Direito Empresarial pela Fundação Getúlio Vargas (FGV). Integrante, na mesma instituição, do Grupo de Pesquisa "Estado, Democracia Constitucional e Direitos Fundamentais". Vitória - ES - Brasil. Advogado. E-mail: luisotaviocosta.adv@gmail.com

2 Doutor e Mestre em Direito Constitucional pela Universidade Federal de Minas Gerais (UFMG). Professor do Departamento de Direito da Universidade Federal do Espírito Santo (UFES). Professor e Coordenador da Faculdade de Direito de Vitória (FDV). Coordenador do Grupo de Pesquisa "Estado, Democracia Constitucional e Direitos Fundamentais" na Faculdade de Direito de Vitória (FDV); Vitória - ES - Brasil. E-mail: daury@terra.com.br 
COSTA, Luís Otávio Monteiro; FABRIZ, Daury Cesar. Deveres fundamentais e soberania popular: a desobediência civil como mecanismo de participação democrática e promoção de direitos fundamentais. Revista Eletrônica Direito e Política, Programa de Pós-Graduação Stricto Sensu em Ciência Jurídica da UNIVALI, Itajaí, v.13, n.1, $1^{0}$ quadrimestre de 2018. Disponível em: www.univali.br/direitoepolitica - ISSN 1980-7791

\section{ABSTRACT}

The article aims to analyse the civil disobedience as a useful instrument for the purposes of the exercise of direct democracy in cases in which they glimpse the edition of unjust laws or that violate rights. It is argued that, in the face of the inefficiency in the employment of mechanisms of direct democracy and of the patent crisis of legitimacy of representatives, the Brazilian people is detached from political tensions that underpin the creation of laws and measures on the part of the government, being the disobedience a non-institutionalized, but effective, political demonstration against unjust laws. In addition, it will seek to demonstrate that, in addition to a fundamental right or a moral duty, civil disobedience, in the light as the republican and democratic principles, can be understood as a fundamental duty to be practiced in situations in which the law or governmental action considered unjust repress rights laid down in the legal system.

Keywords: Popular sovereignty; Civil disobedience; Fundamental duties

\section{INTRODUÇÃO}

A crise de legitimidade que envolve o ambiente político brasileiro, em todas as suas instâncias demonstra alguns aspectos problemáticos da democracia aqui praticada, identificados, a título de exemplo, na insuficiente utilização de instrumentos de democracia direta previstos na Constituição de 1988, mas, sobretudo, no afastamento do cidadão das instâncias decisórias e do cenário político, em que são definidas as políticas públicas e as diretrizes que orientarão os rumos da nação.

Essas duas circunstâncias são suficientes para afirmar que, hodiernamente, não se pode prescindir da necessária a releitura dos mecanismos disponíveis para o povo para fins de manifestação direta a respeito de sua vontade soberana e da forma com a qual almeja ver o poder político sendo materializado na vida cotidiana.

Da mesma forma, é cogente a necessidade de provocação do debate acerca dos meios com os quais pode o povo se reaproximar ativamente dos assuntos políticos, de modo a influenciar as decisões politicamente relevantes, que ganham forma nas leis criadas no âmbito legislativo, e nas medidas governamentais tomadas no âmbito do executivo, especialmente nos casos em que as leis ou medidas governamentais implementadas geram um dever geral de 
COSTA, Luís Otávio Monteiro; FABRIZ, Daury Cesar. Deveres fundamentais e soberania popular: a desobediência civil como mecanismo de participação democrática e promoção de direitos fundamentais. Revista Eletrônica Direito e Política, Programa de Pós-Graduação Stricto Sensu em Ciência Jurídica da UNIVALI, Itajaí, v.13, n.1, 10 quadrimestre de 2018. Disponível em: www.univali.br/direitoepolitica - ISSN 1980-7791

obediência a leis (em sentido amplo) injustas, desprovidas da legitimidade conferida pelo povo.

No presente artigo a questão que se coloca é se a desobediência civil pode ser considerada um instrumento de democracia direta, ainda que não institucionalizado, capaz de reinserir o cidadão nas ações políticas, particularmente nas situações em que é questionada uma lei considerada injusta ou violadora de direitos.

Além disso, questiona-se, a partir das obras de Maria Garcia, Henry Thoreau, Michael Walzer, Ronald Dworkin e de autores que tratam da temática referente aos deveres fundamentais, se é possível afirmar a existência de um dever fundamental de desobediência civil contra leis injustas que violem direitos ou que coloquem em risco as instituições democráticas.

O artigo buscará demonstrar o surgimento e a consolidação do ideal da soberania e da participação popular, discorrendo sobre a prevalência do modelo de democracia representativa no Estado Moderno, bem como a sua crise de legitimidade, cujos efeitos são verificados no distanciamento do povo das instâncias decisórias e das tensões políticas emergentes no meio político-social.

Igualmente, terá como objetivo apresentar as questões conceituais mais relevantes sobre a desobediência civil, na tentativa de analisá-la na perspectiva de uma possível forma de exercício de democracia direta, baseando-se na doutrina de Garcia, Thoreau, Walzer e Dworkin, para, finalmente, analisar a eventual existência de um dever fundamental de desobediência civil contra leis consideradas injustas.

A presente pesquisa se concretiza por meio do emprego do método dedutivo e, ao assumir caráter exploratório e bibliográfico, desenvolve-se por meio de levantamentos bibliográficos de livros, artigos de periódicos especializados. No mais, é construída mediante a análise crítica do material colhido. 
COSTA, Luís Otávio Monteiro; FABRIZ, Daury Cesar. Deveres fundamentais e soberania popular: a desobediência civil como mecanismo de participação democrática e promoção de direitos fundamentais. Revista Eletrônica Direito e Política, Programa de Pós-Graduação Stricto Sensu em Ciência Jurídica da UNIVALI, Itajaí, v.13, n.1, $1^{0}$ quadrimestre de 2018. Disponível em: www.univali.br/direitoepolitica - ISSN 1980-7791

\section{ESTADO DEMOCRÁTICO, SOBERANIA E PARTICIPAÇÃO POPULAR NAS AÇÕES POLÍTICAS}

Durante séculos a organização e o funcionamento dos Estados monárquicos europeus estiveram sujeitados a governos autocráticos cujo poder estava alicerçado num suposto direito emanado diretamente de Deus, configurando um suposto direito divino dos reis. Nesse período histórico, o poder dos monarcas detinha um caráter inquestionável e irredutível frente às comunidades de súditos que sustentavam economicamente os interesses dos soberanos.

O rompimento deste paradigma só viria a ser finalizado com a formação do Estado Moderno, no século XVIII - e, junto com ele, com a sedimentação do ideal moderno de um Estado Democrático -, em decorrência de processos revolucionários eclodidos em diferentes localidades e que representaram a afirmação de um novo marco histórico e político, segundo o qual a autoridade para governar não estaria mais sob o domínio das monarquias absolutistas, mas nas mãos do povo e de seus cidadãos.

Nesse cenário de mudanças, três grandes processos político-sociais destacaramse na fixação prática dos princípios e ideais fundadores do Estado Moderno e da Democracia, a saber: a Revolução Inglesa, fundamentada nas ideias de John Locke e cujo ápice normativo foi alcançado com a elaboração do Bill of Rights, em 1689; a Revolução Americana, com seus respectivos princípios expressados na Declaração de Independência das treze colônias americanas, em 1776; e a Revolução Francesa, cujos princípios foram externados na Declaração dos Direitos do Homem e do Cidadão, em $1789^{3}$.

Esses processos tinham como característica comum o fato de buscarem implantar o modelo democrático de modo a substituir os governos absolutistas dos monarcas pelos governos exercidos com base na vontade manifesta pela maioria dos cidadãos de determinada nação. Delineava-se, naquele momento

3 DALLARI, Dalmo de Abreu. Elementos de teoria geral do Estado. 27. ed. São Paulo: Saraiva, 2007, p. 147. 
COSTA, Luís Otávio Monteiro; FABRIZ, Daury Cesar. Deveres fundamentais e soberania popular: a desobediência civil como mecanismo de participação democrática e promoção de direitos fundamentais. Revista Eletrônica Direito e Política, Programa de Pós-Graduação Stricto Sensu em Ciência Jurídica da UNIVALI, Itajaí, v.13, n.1, 10 quadrimestre de 2018. Disponível em: www.univali.br/direitoepolitica - ISSN 1980-7791

histórico, o princípio da supremacia da vontade do povo em detrimento da vontade de governos autocráticos.

Para além da consagração da soberania popular - que realocou o núcleo de onde emanava o poder do Estado - tais movimentos revolucionários tiveram o condão de fomentar a ideia do exercício de um governo pela maioria por meio do concomitante reconhecimento da existência de direitos naturais inerentes aos indivíduos, em especial os direitos à liberdade e à igualdade, reafirmando-se a concepção jusnaturalista a partir da qual todos os indivíduos são nascidos livres e iguais, estando, assim, aptos a se autogovernarem, caindo por terra a ideia da predestinação divina dos antigos monarcas, soberanos no Estado Absolutista.

Conforme acentua Dallari ${ }^{4}$, a síntese dos referidos movimentos político-sociais reside basicamente em três pontos relacionados à formação do Estado Democrático, quais sejam: a supremacia da vontade popular, na qual o problema da participação popular no governo foi colocado em foco, discutindo-se questões afetas à representatividade, à extensão do direito de sufrágio e aos sistemas eleitorais e partidários; a preservação da liberdade, entendida como o poder de fazer tudo o que não incomodasse terceiros e como o poder de dispor de sua pessoa e de seus bens, sem a interferência do Estado; e a igualdade de direitos, compreendida como a proibição de distinção no gozo de direitos, independentemente de razões econômicas ou de discriminação de classes sociais.

No que tange à supremacia da vontade popular, Pedra ${ }^{5}$ aduz que a ideia democrática formada na era moderna estaria assentada neste princípio, que, por sua vez, corresponderia ao entendimento de que o povo é a única fonte do poder, premissa esta, inclusive, reproduzida no parágrafo único do art. $1^{0}$ da Constituição da República de 1988.

4 DALLARI, Dalmo de Abreu. Elementos de teoria geral do Estado. 27. ed. São Paulo : Saraiva, 2007, p. 150-151.

5 PEDRA, Adriano Sant'Ana. A Constituição viva: poder constituinte permanente e cláusulas pétreas na democracia participativa. Rio de Janeiro: Lumen Juris, 2014, p. 155. 
COSTA, Luís Otávio Monteiro; FABRIZ, Daury Cesar. Deveres fundamentais e soberania popular: a desobediência civil como mecanismo de participação democrática e promoção de direitos fundamentais. Revista Eletrônica Direito e Política, Programa de Pós-Graduação Stricto Sensu em Ciência Jurídica da UNIVALI, Itajaí, v.13, n.1, $1^{0}$ quadrimestre de 2018. Disponível em: www.univali.br/direitoepolitica - ISSN 1980-7791

Ademais, a noção democrática estaria, também, fundada no princípio da participação do povo no poder, cujo significado faria alusão à participação popular direta ou indireta no exercício do poder, com o escopo de que este efetivamente expressasse a vontade popular6. Sua noção estaria atrelada, portanto, a um viés mais operacional da democracia, na medida em que faria referência às formas como se apresentaria a participação do povo no poder político.

É com base neste último princípio, sobretudo, que ganha relevância o debate acerca dos tipos de democracia comumente aceitos como formas para o efetivo funcionamento e exercício do poder político pelo povo. Isso ocorre porque ação política ao alcance do cidadão, isto é, o próprio exercício da cidadania geralmente se amolda a três formas distintas, quais sejam: a democracia direta, a democracia representativa e a democracia participativa.

A democracia direta deve ser entendida como "(...) o exercício do poder político pelo povo, reunido em assembleia plenária da coletividade ${ }^{7 \prime}$. Em conformidade com o pensamento de Bobbio:

Para que exista democracia direta no sentido próprio da palavra, isto é, no sentido em que direito quer dizer que o indivíduo participa ele mesmo nas deliberações que lhe dizem respeito, é preciso que entre os indivíduos deliberantes e a deliberação que Ihe diz respeito não exista nenhum intermediário ${ }^{8}$.

Como se pode observar, nesse modelo de democracia, que remonta à Antiguidade, a ação política do povo era exercitada diretamente num cenário em que as preocupações do corpo social estavam voltadas ao interesse dos cidadãos pelos interesses públicos, interpretados como sendo de maior importância se cotejados com os respectivos interesses privados inerentes à cada pessoa.

\footnotetext{
6 PEDRA, Adriano Sant'Ana. A Constituição viva: poder constituinte permanente e cláusulas pétreas na democracia participativa. Rio de Janeiro: Lumen Juris, 2014, p. 155.

7 PEDRA, Adriano Sant'Ana. A Constituição viva: poder constituinte permanente e cláusulas pétreas na democracia participativa. Rio de Janeiro: Lumen Juris, 2014, p. 155.

8 BOBBIO, Norberto. O futuro da democracia. 9a. Ed. Trad. Marco Aurélio Nogueira. São Paulo: Paz e Terra, 2000, p. 63.
} 
COSTA, Luís Otávio Monteiro; FABRIZ, Daury Cesar. Deveres fundamentais e soberania popular: a desobediência civil como mecanismo de participação democrática e promoção de direitos fundamentais. Revista Eletrônica Direito e Política, Programa de Pós-Graduação Stricto Sensu em Ciência Jurídica da UNIVALI, Itajaí, v.13, n.1, $1^{0}$ quadrimestre de 2018. Disponível em: www.univali.br/direitoepolitica - ISSN 1980-7791

É bem verdade que esse tipo de democracia só era possível em decorrência do número reduzido de habitantes das cidades-estados gregas, assim como o ainda mais diminuto número de cidadãos componentes daquele corpo social, haja vista que a qualidade de cidadão livre ${ }^{9}$ era atribuída a pouquíssimas pessoas detentoras do status social que Ihes garantisse a possibilidade de não trabalhar e de se dedicarem exclusivamente à tratativa dos assuntos públicos.

Analisada da perspectiva da sociedade contemporânea tem-se que a democracia direta é praticamente inconcebível, na medida em que a complexidade das relações políticas e sociais somadas ao grande número de cidadãos que integram tantas nações democráticas torna materialmente impossível a sua realização. Nessa linha, Pedra assevera que:

Hodiernamente a democracia exclusivamente direta é impraticável em razão da impossibilidade material de sua realização, devido ao grande número de cidadãos que compõem o Estado, além de sua incapacidade de compreender os problemas técnicos e complexos do Estado contemporânea, constituindo-se assim uma "reminiscência histórica ou uma curiosidade quase que folclórica ${ }^{10 "}$.

Exatamente em virtude de alguns dos problemas identificados na operacionalização da democracia direta, bem como em função do advento de uma série de direitos políticos reconhecidos após as revoluções democráticas dentre eles o direito de votar e ser votado -, passou-se a falar na democracia dos modernos, notadamente caracterizada pela materialização do modelo de democracia representativa, no qual os cidadãos aptos ao exercício de seus direitos políticos poderiam eleger representantes responsáveis pela defesa dos interesses gerais da coletividade. Conforme delineado por Bobbio:

\footnotetext{
9 Devido a isso, é oportuna a reflexão de Bonavides ao afirmar que "o homem moderno, via de regra, 'homem de massa', precisa de prover, de imediato, às necessidades materiais de sua existência. Ao contrário do cidadão livre ateniense, não se pode volver ele de todo para a análise dos problemas de governo, para a faina penosa das questões administrativas, para o exame e interpretação dos complicados temas relativos à organização política e jurídica e econômica da sociedade" (BONAVIDES, Paulo. Ciência Política. $10^{\circ}$ edição, $9^{a}$ tiragem Editora Malheiros, 2000, p. 353).
}

10 PEDRA, Adriano Sant'Ana. A Constituição viva: poder constituinte permanente e cláusulas pétreas na democracia participativa. Rio de Janeiro: Lumen Juris, 2014, p. 156. 
COSTA, Luís Otávio Monteiro; FABRIZ, Daury Cesar. Deveres fundamentais e soberania popular: a desobediência civil como mecanismo de participação democrática e promoção de direitos fundamentais. Revista Eletrônica Direito e Política, Programa de Pós-Graduação Stricto Sensu em Ciência Jurídica da UNIVALI, Itajaí, v.13, n.1, $1^{0}$ quadrimestre de 2018. Disponível em: www.univali.br/direitoepolitica - ISSN 1980-7791

A expressão "democracia representativa" significa genericamente que as deliberações coletivas, isto é, as deliberações que dizem respeito à coletividade inteira, são tomadas não diretamente por aqueles que dela fazem parte mas por pessoas eleitos para esta finalidade ${ }^{11} 12$.

Na sociedade contemporânea é este o modelo predominante no que diz respeito aos tipos de democracia aplicados, mormente em razão do grande número de cidadãos que integram o Estado e, também, em virtude da incessante demanda por leis sobre os mais variados assuntos.

Ocorre que, ainda assim, é este um modelo que carrega consigo problemas de difícil resolução, concernentes a cada vez mais urgente necessidade de oportunizar a participação mais direta do povo nos assuntos políticos na medida em que é evidente o caráter meramente formal que a soberania popular possui no âmbito do modelo representativo da democracia moderna.

Mesmo sendo o titular do poder soberano, neste modelo o papel exercido pelo povo acaba por ser cumprido com o simples ato de eleger periodicamente os seus representantes, outorgando-lhes o poder de, em seu nome, agir politicamente em prol dos interesses gerais da comunidade. No panorama atual, é esta uma função demasiadamente simplória, principalmente quando se conclui que os modelos político-representativo, econômico e jurídico, formados pela sociedade industrial e capitalista, se encontram em crise ${ }^{13}$.

Particularmente no contexto brasileiro, a título de exemplo, pode-se citar o nítido descompasso entre as demandas identificadas no seio da sociedade e os atos executivos e legislativos de seus representantes democraticamente eleitos,

11 BOBBiO, Norberto. O futuro da democracia. 9a. Ed. Trad. Marco Aurélio Nogueira. São Paulo: Paz e Terra, 2000, p. 56.

$12 \mathrm{Na}$ mesma linha traçada por Bobbio, Zaneti Jr. afirma que "as características que descrevem a democracia representativa podem ser identificadas, no aspecto geral, pelo fato de as decisões dos interesses da coletividade não serem tomadas diretamente por aqueles a quem dizem respeito, mas, sim, por representantes eleitos para tanto; no particular, nas democracias representativas modernas (objetivamente no caso do Brasil), o representante é fiduciário de um mandato irrevogável, ficando vedado o mandato imperativo (princípio da proibição do mandato imperativo) e portanto sendo ele representante dos interesses gerais" (ZANETI JúNIOR, Hermes. A constitucionalização do processo. 2. ed. São Paulo: Atlas, 2014, p. 123).

13 ZANETI JÚNIOR, Hermes. A constitucionalização do processo. 2. ed. São Paulo: Atlas, 2014 , p. 122. 
COSTA, Luís Otávio Monteiro; FABRIZ, Daury Cesar. Deveres fundamentais e soberania popular: a desobediência civil como mecanismo de participação democrática e promoção de direitos fundamentais. Revista Eletrônica Direito e Política, Programa de Pós-Graduação Stricto Sensu em Ciência Jurídica da UNIVALI, Itajaí, v.13, n.1, $1^{0}$ quadrimestre de 2018. Disponível em: www.univali.br/direitoepolitica - ISSN 1980-7791

especialmente em assuntos relacionados à formulação de políticas públicas e serviços públicos eficientes a partir de direitos fundamentais sociais previstos constitucionalmente, assim como em temáticas associadas ao controle da criminalidade, com maior destaque para os crimes contra a vida e contra o patrimônio público.

É clara a tendência doutrinária de se defender uma junção óbvia de ambos os modelos até aqui citados, uma vez que, isoladamente, não são autossuficientes a ponto de satisfazerem materialmente os pressupostos da soberania popular.

Fala-se, por conseguinte, na efetivação de uma democracia participativa caracterizada pela coexistência de instrumentos de democracia representativa com outros da democracia direita, como o referendo, o plebiscito, a revogação, a inciativa popular ${ }^{14}$. Essa visão é compartilhada por Zaneti Jr., quando acentua que:

A questão central não é a mera opção por um ou outro sistema, o que apenas aprofundaria a crise de suas insuficiências apontadas; antes, existe uma convivência harmônica e obrigatória entre as duas formas democráticas (direta e representativa) que aponta para uma almejada "democracia integral". Portanto, de uma perspectiva de oposição, democracia direta versus democracia representativa, opta-se por uma perspectiva de convergência, de sorte que se possibilite uma democracia mais participativa e de cunho social, daí o respeito obrigatório ao "princípio formal", que se agrega á lei elaborada pelos representes eleitos em parlamento, nos Estados democráticos, como garantia da dignidade e estabilidade da legislação ${ }^{15}$.

Nesta modalidade de democracia a alienação política traduzida na ideia de que o poder é do povo, mas o governo é dos representantes é mitigada em favor da fixação de uma forma de democracia em que "(...) a soberania está com o povo,

14 PEDRA, Adriano Sant'Ana. A Constituição viva: poder constituinte permanente e cláusulas pétreas na democracia participativa. Rio de Janeiro: Lumen Juris, 2014, p. 160.

15 ZANETI JÚNIOR, Hermes. A constitucionalização do processo. 2. ed. São Paulo: Atlas, 2014 , p. 124. 
COSTA, Luís Otávio Monteiro; FABRIZ, Daury Cesar. Deveres fundamentais e soberania popular: a desobediência civil como mecanismo de participação democrática e promoção de direitos fundamentais. Revista Eletrônica Direito e Política, Programa de Pós-Graduação Stricto Sensu em Ciência Jurídica da UNIVALI, Itajaí, v.13, n.1, $1^{0}$ quadrimestre de 2018. Disponível em: www.univali.br/direitoepolitica - ISSN 1980-7791

e o governo, mediante o qual essa soberania se comunica ou exerce, pertence por igual ao elemento popular nas matérias mais importantes da vida pública ${ }^{16 " .}$

Apesar disso, as idealizações acima acenadas parecem estar ainda muito distantes da realidade política brasileira. Raramente instrumentos como o referendo, o plesbicito ou projetos de iniciativa popular são empregados, fato este que faz predominar o exercício da democracia representativa, ainda que em crise de legitimidade.

Por outro lado, o não uso de mecanismos de democracia direta capazes de aproximar o cidadão, grupos ou a sociedade como um todo, tem como efeito prático o afastamento do cidadão das tensões políticas reais identificadas na sociedade civil, situação esta que, em certa medida, põe em xeque a soberania popular, revelando a urgência de meios que permitam a construção de uma discursividade democrática, ainda que fora dos limites institucionais ${ }^{17}$.

É nesse sentido que urge a discussão a respeito das possibilidades e da legitimidade de atos de desobediência civil a fim de se averiguar o seu fundamento autorizativo e a sua eficácia para fins de garantia da soberania popular, dos direitos previstos no ordenamento jurídico pátrio e do ideal democrático, pontualmente nos casos em que se esteja diante de leis ou medidas governamentais injustas.

\section{O DeVer geral de ObediênCIA Às LeIS e A DESObediênCIA CIVIL NAS PERSPECTIVAS DE GARCIA, THOREAU, WALZER E DWORKIN}

A forma mais evidente da expressão da soberania do povo é a lei, instrumento este por meio do qual se perfaz no plano jurídico-normativo a vontade de cada cidadão apto a exercer a sua parcela do poder político. É por intermédio das leis que as autoridades constituídas exercitam os poderes a eles outorgados, devendo, para isso, estar amparados na legalidade e na legitimidade que constituem o exercício do poder, de modo a, respectivamente, aferir a

\footnotetext{
${ }^{16}$ BONAVIDES, Paulo. Ciência Política. $10^{\circ}$ edição, 9a tiragem Editora Malheiros, 2000, p. 355.

17 LUCAS, Doglas Cesar. A desobediência civil na teoria jurídica de Ronald Dworkin. Revista de Direitos Fundamentais e Democracia. Curitiba, v. 16, n. 16, p. 116-129, julho/dezembro, 2014, p. 129.
} 
COSTA, Luís Otávio Monteiro; FABRIZ, Daury Cesar. Deveres fundamentais e soberania popular: a desobediência civil como mecanismo de participação democrática e promoção de direitos fundamentais. Revista Eletrônica Direito e Política, Programa de Pós-Graduação Stricto Sensu em Ciência Jurídica da UNIVALI, Itajaí, v.13, n.1, $1^{0}$ quadrimestre de 2018. Disponível em: www.univali.br/direitoepolitica - ISSN 1980-7791

conformação dos atos de autoridade ao conteúdo das leis vigentes e, ainda, a sua correspondência aos valores e aspirações de certa comunidade política.

Pode-se afirmar que é através das leis e de seus aspectos relacionados à legalidade e à legitimidade e, portanto, ao cumprimento das leis e a busca pela adesão não impositiva da vontade do Estado, que se estabelece um meio termo para o regular processamento das atividades que se constituem no ambiente social, porquanto é a lei um mecanismo útil para regrar tanto as liberdades inerentes aos indivíduos, quanto o poder exercido pelo Estado. Nesse mesmo sentido, Garcia defende que:
A lei, expressando o Direito, determina paritariamente a contenção do poder do Estado, dentro da experiência social vivenciada, em cada momento histórico, e, concomitantemente, a limitação dos direitos humanos, melhor dito, a sua enquadratura jurídica - o das liberdades, na medida em que tais direitos são assegurados a todos os homens, tendência do Estado de Direito. Elo que relacionada juridicamente poder e liberdade, Estado e Indivíduo, a lei, no entanto, somente poderá representar esse elemento de conciliação quando tender à realização da justiça - à qual ascende o Direito ${ }^{18}$.

Daí entender que a vida em uma sociedade vinculada aos parâmetros de um Estado de Democrático de Direito está vinculada a um dever geral de obediência às leis, à Constituição e às medidas governamentais nelas pautadas, tanto sob a perspectiva da legalidade, quanto da legitimidade. Apoiando-se nas lições de Rawls a respeito do dever de obediências às leis justas, Weber coloca que:

Não há dificuldades em admitir que devemos obedecer a leis justas. A convivência harmônica e os pactos sociais requerem isso de cada cidadão. Este tem consciência de que os benefícios dessa obediência Ihe asseguram a realização dos direitos fundamentais e das liberdades básicas. Foi para isso que foi criado o Estado e toda a organização social. (...) temos um dever natural de obedecer a uma Constituição justa e de apoiar instituições justas ${ }^{19}$.

18 GARCIA, Maria. Desobediência civil: direito fundamental. 2. ed. São Paulo : Editora Revista dos Tribunais, 2004, p. 72-73.

19 WEBER, Thadeu. Ética, direitos fundamentais e obediência à Constituição. Veritas (Porto Alegre), v. 51, n. 1, 2007, p. 99. 
COSTA, Luís Otávio Monteiro; FABRIZ, Daury Cesar. Deveres fundamentais e soberania popular: a desobediência civil como mecanismo de participação democrática e promoção de direitos fundamentais. Revista Eletrônica Direito e Política, Programa de Pós-Graduação Stricto Sensu em Ciência Jurídica da UNIVALI, Itajaí, v.13, n.1, $1^{0}$ quadrimestre de 2018. Disponível em: www.univali.br/direitoepolitica - ISSN 1980-7791

A questão mais controversa recai sobre o dever de obediência de leis ou medidas governamentais injustas, ou ainda que venham violar direitos positivados. É precisamente nesse cenário de discussão que encontra ressonância a temática da desobediência civil e dos respectivos atos de desobediência a leis ou medidas governamentais tidas como injustas por cidadãos, principalmente em função do suposto não atendimento aos princípios de justiça ou de moralidade erigidos naquela comunidade política.

Convém retomar a ideia já externada de que a prevalência do fracassado modelo representativo de democracia vigente no Brasil favorece o alto grau de intervenção de um Legislativo que não representa a essência dos interesses gerais dos cidadãos e, ao mesmo tempo, o distanciamento destes cidadãos das ações políticas relevantes para a definição dos rumos da comunidade de que faz parte. O efeito direto desta realidade é a intensa produção de leis que não raras vezes estão dissociadas do interesse público.

Assim, exsurge a necessidade de se repensar o Estado ${ }^{20}$ e os instrumentos democráticos passíveis de utilização pelo povo para fins de concretizar a sua participação no exercício do poder político, sendo a desobediência civil uma das formas a serem consideradas, especialmente por sua característica peculiar de se materializar por meio de um "agir" ou de um "não agir" por parte do cidadão, ou, em outras palavras, por meio de um ato de desobediência ao referido dever geral de obediências às leis.

Há que ressaltar que a diversidade das abordagens conferidas pela doutrina, de modo que, a depender do autor estudado, é manifesta a distinção entre um ou outro aspecto para fins de conceituação do que venha a ser e a configurar a desobediência civil, o que demonstra que, na maioria dos casos, a sua completa

\footnotetext{
20 Segundo Garcia, "esse 'repensar do Estado' e as formas sutis de opressão, a dominação tecnocrática e tecnológica, a comunicação de massas - a cidadania como expressão máxima do direito à liberdade - aqui entendida, sempre, no sentido de participação política ou 'como opção política de vida' (Arendt) envolvem, inelutavelmente, novas formas de participação direta do cidadão no exercício do poder pelo Estado e tem, como uma de suas prerrogativas, a desobediência civil, num primeiro momento, forma de participação pelo non agere, diante da lei ou do ato emanado da autoridade ou de ação, em desobediência ou de um agir em prol da participação política (tomada de decisão)" (GARCIA, Maria. Desobediência civil: direito fundamental. 2. ed. São Paulo: Editora Revista dos Tribunais, 2004, p. 261).
} 
COSTA, Luís Otávio Monteiro; FABRIZ, Daury Cesar. Deveres fundamentais e soberania popular: a desobediência civil como mecanismo de participação democrática e promoção de direitos fundamentais. Revista Eletrônica Direito e Política, Programa de Pós-Graduação Stricto Sensu em Ciência Jurídica da UNIVALI, Itajaí, v.13, n.1, $1^{0}$ quadrimestre de 2018. Disponível em: www.univali.br/direitoepolitica - ISSN 1980-7791

compreensão deve se dar à luz das reflexões alcançadas por determinado autor, considerado isoladamente.

Thoreau, por exemplo, considera que ao cidadão não cabe abrir mão de sua própria consciência em prol do legislador e das leis por ele criadas, tendo em vista que as leis não necessariamente representariam ideais de justiça e moralidade. O seu raciocínio é bem claro e direto, conforme se pode observar quando afirma que "a lei nunca tornou os homens sequer um pouquinho mais justos $^{21 " .}$. De modo complementar, acentua o autor que:

Não é obrigação de um homem, evidentemente, dedicar-se à erradicação de um mal qualquer, nem mesmo do maior que exista; ele pode muito bem ter outras preocupações que o absorvam. Mas é seu dever, pelo menos, manter as mãos limpas, e, mesmo sem pensar no assunto, recusar o apoio prático ao que é errado 22 .

Enquanto Thoreau concentra seus esforços na explicação da desobediência civil baseada na objeção de consciência, Walzer trata do tema na perspectiva da suposta existência de uma obrigação de desobedecer a certas ordens legais, sejam elas de cunho religioso, político ou moral.

Acrescenta o autor que a desobediência é classificada quase sempre como um ato coletivo - justificado pelos valores do grupo ${ }^{23}$-, desencadeado por uma eventual incompatibilidade de obrigações assumidas no âmbito de um pequeno grupo com obrigações adquiridas em um grupo de maior extensão, geralmente o Estado $^{24}$.

Outro aspecto relevante diz respeito à distinção feito por Walzer entre desobediência civil e atos revolucionários tendentes à abolição total da ordem legal vigente ou a substituição de um governo por outro, uma vez que

21 THOREAU, Henry David. A desobediência civil. Tradução José Geraldo Couto. São Paulo: Penguin Classics Companhia das Letras, 2012, p. 9.

22 THOREAU, Henry David. A desobediência civil. Tradução José Geraldo Couto. São Paulo: Penguin Classics Companhia das Letras, 2012, p. 15.

23 WALZER, Michael. Das obrigações políticas. Ensaios sobre a desobediência, guerra e cidadania. Rio de Janeiro: Zahar, 1977, p. 10.

24 WALZER, Michael. Das obrigações políticas. Ensaios sobre a desobediência, guerra e cidadania. Rio de Janeiro: Zahar, 1977, p. 12. 
COSTA, Luís Otávio Monteiro; FABRIZ, Daury Cesar. Deveres fundamentais e soberania popular: a desobediência civil como mecanismo de participação democrática e promoção de direitos fundamentais. Revista Eletrônica Direito e Política, Programa de Pós-Graduação Stricto Sensu em Ciência Jurídica da UNIVALI, Itajaí, v.13, n.1, $1^{0}$ quadrimestre de 2018. Disponível em: www.univali.br/direitoepolitica - ISSN 1980-7791

movimentos que culminem em atos de desobediência civil, do seu ponto de vista, devem almejar a modificação parcial da ordem legal, naquilo em que entendam ser social ou moralmente injusto. De acordo com o autor:

Alguns grupos anunciam o que, na verdade, são reivindicações totais. Seus membros são obrigados, sempre que recebam ordens para tal, a desafiar o sistema legal estabelecido, a derrubar e substituir um governo por outro e a atacar a própria existência da sociedade maior. São grupos revolucionários. Há outros, no entanto, que fazem reivindicações apenas parciais. Exigem que a sociedade maior reconheça sua autoridade numa determinada área da vida social ou política e limitam-se a essa exigência. Exigem que seus membros desobedeçam em determinados momentos, e não a todo o momento, e que recusem-se a cumprir certas ordens legais, e não toda ordem legal ${ }^{25}$.

Um exemplo sobre essa diferenciação pode ser colhido da recente reivindicação promovida pelo povo da região da Catalunha, na Espanha, em outubro de 2017. Após anos de reivindicações pacíficas sustentadas por argumentos separatistas, que culminaram na realização de um referendo não reconhecido pelo governo espanhol, o povo catalão decidiu declarar nas urnas a sua independência, ato este ratificado pelo Parlamento local, desafiando o governo espanhol e, principalmente, as leis e a Constituição espanhola.

Á luz do pensamento de Walzer, seria este um exemplo de um grupo minoritário que, mediante atos revolucionários, ainda que pacíficos, promovem uma reivindicação total, cujo resultado, se alcançado, importaria na substituição do governo e da ordem legal a que estavam submetido. Por certo, de acordo com a doutrina do autor, seria esta uma situação na qual a prática de atos de desobediência civil restaria descaracterizada.

Garcia ${ }^{26}$, por sua vez, ao analisar a desobediência civil sob a ótica dos direitos fundamentais, entende que ela pode consistir numa resistência passiva, ou então numa resistência ativa manuseada por meio de atos não jurisdicionais perante os

25 WALZER, Michael. Das obrigações políticas. Ensaios sobre a desobediência, guerra e cidadania. Rio de Janeiro: Zahar, 1977, p. 16-17.

26 GARCIA, Maria. Desobediência civil: direito fundamental. 2. ed. São Paulo : Editora Revista dos Tribunais, 2004, p. 297. 
COSTA, Luís Otávio Monteiro; FABRIZ, Daury Cesar. Deveres fundamentais e soberania popular: a desobediência civil como mecanismo de participação democrática e promoção de direitos fundamentais. Revista Eletrônica Direito e Política, Programa de Pós-Graduação Stricto Sensu em Ciência Jurídica da UNIVALI, Itajaí, v.13, n.1, $1^{0}$ quadrimestre de 2018. Disponível em: www.univali.br/direitoepolitica - ISSN 1980-7791

Poderes Públicos, fundamentando-se, para isso, nos princípios democrático e republicano, que garantiriam o direito de participação do cidadão nas esferas essenciais do Estado.

Para essa autora, a desobediência civil - em sendo um direito subjetivo público fundado nas prerrogativas da cidadania - admitiria como titulares tanto o cidadão considerado individualmente, como um grupo de cidadãos, desde que voltados ao não atendimento ao ato de autoridade, à revogação ou alteração de uma lei contrária à ordem constitucional ou aos direitos fundamentais. A forma de seu exercício estaria sujeitada ao uso do o instrumento previsto no inciso XXXIV, "a", do art. $5^{\circ}$ da Constituição, que se refere ao direito de petição aos Poderes Públicos para fins de defesa de direitos ou contra ilegalidade ou abuso de poder $^{27}$.

Para Dworkin, a desobediência civil constitui uma experiência política na qual cidadãos independentes, dotados de um intenso senso de justiça em relação a questões morais e políticas, se posicionam em favor da recolocação da legitimidade fundamental do governo e da comunidade, de modo que o aparato jurídico-normativo reflita a moral da comunidade de que faz parte, sem que para isso seja colocada em questão a ruptura do ordenamento jurídico vigente.

Quanto a este ponto, especificamente, pode-se notar uma semelhança na abordagem conferida por Dworkin à desobediência civil, se comparada à abordagem oferecida por Walzer. Isso porque em sua teoria operacional da desobediência civil Dworkin promove a diferenciação desses atos de quaisquer outras ações que venham a configurar uma simples atividade criminosa comum, ou, então, ações que identifiquem a ocorrência de uma guerra civil em determinado território. Dworkin assegura que:

A desobediência civil, quaisquer que sejam as diferenças adicionais que possamos desejar estabelecer nessa categoria geral, é muito diferente da atividade criminosa comum, motivada por egoísmo, raiva, crueldade ou loucura. É também diferente - isso é mais facilmente negligenciado -

27 GARCIA, Maria. Desobediência civil: direito fundamental. 2. ed. São Paulo : Editora Revista dos Tribunais, 2004, p. 298. 
COSTA, Luís Otávio Monteiro; FABRIZ, Daury Cesar. Deveres fundamentais e soberania popular: a desobediência civil como mecanismo de participação democrática e promoção de direitos fundamentais. Revista Eletrônica Direito e Política, Programa de Pós-Graduação Stricto Sensu em Ciência Jurídica da UNIVALI, Itajaí, v.13, n.1, $1^{0}$ quadrimestre de 2018. Disponível em: www.univali.br/direitoepolitica - ISSN 1980-7791

da guerra civil que irrompe em um território quando um grupo desafia a legitimidade do governo ou das dimensões da comunidade política. A desobediência civil envolve aqueles que não desafiam a autoridade de maneira tão fundamental. Eles não veem a si mesmos - nem pedem aos outros que os vejam desta forma - como pessoas que estão buscando alguma ruptura ou reorganização constitucional básicas. Aceitam a legitimidade fundamental do governo e da comunidade; agem mais para confirmar que contestar seu dever como cidadãos ${ }^{28}$.

Afora isso, tem a preocupação de separar os atos de desobediência civil em três tipos distintos, classificados de acordo com a circunstância motivadora da desobediência. São eles: a desobediência baseada na integridade; a desobediência baseada na justiça; e a desobediência baseada em política.

No que tange à desobediência baseada na integridade, Dworkin a explica como a situação em que alguém se nega a cumprir determinado mandamento legal por entender que a regra imposta exige que ele se comporte de maneira imoral, isto é, em desacordo com a sua própria consciência. Para isso o autor norteamericano cita, exemplificativamente, a hipótese em que alguém creia ser errado negar ajuda a um escravo fugido que bata à sua porta, ou então entregá-lo às autoridades, por não compartilhar da moral expressada nesta norma ${ }^{29}$.

Trata-se este primeiro tipo de desobediência civil de hipótese similar àquela preconizada por Thoreau, quando defende o exercício da resistência, por intermédio de atos de desobediência civil fundados na expressão da objeção de consciência de quem os pratica, vale dizer, mediante um não fazer, ou então, por meio de uma conduta de caráter defensivo voltado a não satisfação daquilo que a consciência do indivíduo o proíbe de fazer.

\footnotetext{
28 DWORKIN, Ronald. Uma questão de princípio. Tradução Luís Carlos Borges. São Paulo: Martins Fontes, 2000, p. 155.

29 "Quando consideramos a primeira pergunta - sobre o que é certo que as pessoas façam se acreditam que as leis estão erradas - tudo depende do tipo geral de desobediência civil que temos em mente. [...]. Alguém que acredite ser profundamente errado negar ajuda a um escravo fugitivo que bate à sua porta e, pior ainda, entrega-lo às autoridades, acha que a Lei do Escravo Fugitivo exige que ele se comporte de maneiro imoral. [...]. Chamarei a desobediência civil de pessoas nessa circunstância de desobediência 'baseada na integridade'" (DWORKIN, Ronald. Uma questão de princípio. Tradução Luís Carlos Borges. São Paulo: Martins Fontes, 2000, p. 157).
} 
COSTA, Luís Otávio Monteiro; FABRIZ, Daury Cesar. Deveres fundamentais e soberania popular: a desobediência civil como mecanismo de participação democrática e promoção de direitos fundamentais. Revista Eletrônica Direito e Política, Programa de Pós-Graduação Stricto Sensu em Ciência Jurídica da UNIVALI, Itajaí, v.13, n.1, $1^{0}$ quadrimestre de 2018. Disponível em: www.univali.br/direitoepolitica - ISSN 1980-7791

No que diz respeito à desobediência civil baseada na justiça, Dworkin faz menção à situação em que a ação desencadeadora da desobediência civil se respalda na tentativa de desmantelar políticas que considerem injustas por representarem, principalmente, a opressão de grupos de maiores sobre grupos de minoria.

Pode-se deduzir que a imersão na realidade histórica norte-americana, onde são fartos os exemplos de conquistas recentes de direitos civis por grupos minoritários, como, por exemplo, os direitos civis conquistados pelos negros, faz com que Dworkin novamente recorra à circunstância em que cidadãos negros submetidos a regras segregacionistas as desobedecem para protestarem pacificamente contra a política adotada ${ }^{30}$.

Nesse tipo de desobediência civil, diferentemente da primeira, a ação praticada contra a lei considerada imoral ou injusta apresente um viés ativo da desobediência civil. Certamente, em determinados casos pode-se afirmar a inutilidade prática da permanência dos desobedientes em um estado passivo, de "não fazer", o que atesta a existência de distintas funcionalidades no exercício da desobediência civil, a depender do tipo adotado e da circunstância analisada.

Finalmente, no tocante à desobediência baseada em política, Dworkin alude à conjuntura em que a ação de desobediência civil não está amparada em convicções de princípio que importem na crença de que determinada lei seja imoral ou injusta. Neste último caso, o fundamento utilizado para embasar a desobediência civil encontra-se na percepção de que a lei combatida importa riscos contra os bens jurídicos a que determinada comunidade dê valor, pouco

\footnotetext{
30 "Compare com a posição moral dos negros que violaram a lei durante o movimento pelos direitos civis, sentando-se em balcões que lhes eram proibidos em busca do privilégio de comer hambúrgueres gordurosos ao lado de pessoas que os odiavam. Seria errôneo dizer que estavam lá por obedecer à consciência, que violaram a lei porque não podiam, com integridade, fazer o que a lei exigia. Ninguém tem o dever moral geral de buscar e reivindicar direitos que acredita possuir. Eles agiram por uma razão diferente: para opor-se a uma política que consideravam injusta e alterá-la, uma política de opressão de uma minoria pela maioria. [...]. Essa é a desobediência civil 'baseada na justiça'" (DWORKIN, Ronald. Uma questão de princípio. Tradução Luís Carlos Borges. São Paulo: Martins Fontes, 2000, p. 157-158).
} 
COSTA, Luís Otávio Monteiro; FABRIZ, Daury Cesar. Deveres fundamentais e soberania popular: a desobediência civil como mecanismo de participação democrática e promoção de direitos fundamentais. Revista Eletrônica Direito e Política, Programa de Pós-Graduação Stricto Sensu em Ciência Jurídica da UNIVALI, Itajaí, v.13, n.1, $1^{0}$ quadrimestre de 2018. Disponível em: www.univali.br/direitoepolitica - ISSN 1980-7791

importando se tais riscos se voltam contra uma minoria específica ou contra a maioria da sociedade ${ }^{31}$.

\section{O DEVER DE DESOBEDIÊNCIA CIVIL À LUZ DO REGIME JURÍDICO DOS DEVERES FUNDAMENTAIS}

O exame acerca da real situação da democracia brasileira tem demonstrado que o modelo atualmente vigente não mais satisfaz às expectativas e anseios de um povo cujo poder político é negligenciado tanto pela ineficiência e corruptibilidade generalizada de seus representantes eleitos - em todas as instâncias de poder e em todos os entes da federação -, quanto pelo acanhado emprego dos instrumentos de democracia direta, previstos na Constituição da República, que, em tese, aproximariam o cidadão das tensões políticas que tendem a orientar os rumos políticos, sociais, econômicos e jurídicos da sociedade.

Como visto anteriormente, diante desta complexa crise de legitimidade que incide sobre os representantes da soberania popular e da modesta utilização de mecanismos como, por exemplo, o plebiscito, o referendo e a inciativa popular, é plausível conceber a desobediência civil como um instrumento não institucionalizado adequado para o exercício do poder político diretamente pelo povo, especificamente nos casos em que se vislumbre a edição de leis ou, ainda, de medidas governamentais injustas.

Apesar disso, podem-se aventar, também, outras importantes questões afetas à desobediência civil, tal como a sua adequação a categorias jurídicas erigidas à luz dos princípios e do regime constitucional adotado pela Lei Maior brasileira. No presente trabalho, de forma pontual, restringem-se estas discussões à tentativa de verificação da desobediência civil - sob o viés da soberania popular e do

\footnotetext{
31 "Esses dois primeiros tipos de desobediência civil envolvem, embora de diferentes maneiras, convicções de princípio. Há um terceiro tipo que envolve julgamento de política. As pessoas às vezes violam a lei não porque acreditam que a política a que se opõem é imoral ou injusta, tal como descrito, mas porque acham que é insensata, estúpida e perigosa para a maioria, assim como para qualquer minoria. Os recentes protestos contra a colocação de mísseis norteamericanos na Europa, na medida em que violaram a lei local, foram, na maioria das vezes, ocorrências desse terceiro tipo de desobediência civil, que chamarei de desobediência 'baseada em política'" (DWORKIN, Ronald. Uma questão de princípio. Tradução Luís Carlos Borges. São Paulo: Martins Fontes, 2000, p. 158).
} 
COSTA, Luís Otávio Monteiro; FABRIZ, Daury Cesar. Deveres fundamentais e soberania popular: a desobediência civil como mecanismo de participação democrática e promoção de direitos fundamentais. Revista Eletrônica Direito e Política, Programa de Pós-Graduação Stricto Sensu em Ciência Jurídica da UNIVALI, Itajaí, v.13, n.1, $1^{0}$ quadrimestre de 2018. Disponível em: www.univali.br/direitoepolitica - ISSN 1980-7791

exercício da cidadania - como sendo um direito fundamental, um dever moral, ou, até mesmo, um dever fundamental.

A respeito dessa questão, Dworkin se posiciona no sentido de que, no plano jurídico, a desobediência civil não constituiria um direito fundamental, mas uma consequência lógica e possível decorrente de um eventual conflito entre a lei e direitos considerados básicos em determinada ordem jurídica, ou então, entre a lei e princípio morais. Nessa perspectiva, não poderia a desobediência civil ser tratada como um direito estabelecido legalmente, mas tão somente como um direito moral a ser praticado à luz dos princípios morais e dos valores que compõe uma comunidade política em particular. Sobre essa abordagem de Dworkin, Javier de Lucas elucida que:

La desobediencia civil no es, para nuestro autor, um derecho que se tiene cuando se producen situaciones de conflicto entre la ley y derechos básicos, o entre la ley y los principios morales, sino más bien una consecuencia o, mejor, uma característica de los propios derechos fundamentales que no pueden negarse si se admite su carácter fuerte. Es así como hay que entender su tesis de que no resulta correcto plantear el problema de la desobediencia civil como si se tratara de un derecho en el sentido estricto [...]. La conclusión de Dworkin es, por tanto, que no existe derecho legal a la desobediencia civil, sino que se trata de un derecho moral, que no hay justificación em el plano jurídico, lo que, como suele destacarse, supondría una contradición conceptual ${ }^{32}$.

Em contrapartida, da mesma forma que situa a desobediência civil como um direito moral, Dworkin crê que este atributo da experiência política em que está envolvido o cidadão pode gerar algum tipo de dever moral. Esse aspecto é delineado quando trata da desobediência civil "baseada na integridade", explicando que diferentemente da desobediência "baseada na justiça" ou "em política", nesta modalidade o indivíduo age - ou deixa de agir - em função de um dever moral projetado pela própria consciência33, amoldando-se a sua

32 LUCAS, Javier de. Una consecuencia de la tesis de los derechos: la desobediencia civil segun R. Dworkin. In: Doxa n², 1985, p. 202-203.

33 Nesse sentido, vide Dworkin (2000, p. 157-158). 
COSTA, Luís Otávio Monteiro; FABRIZ, Daury Cesar. Deveres fundamentais e soberania popular: a desobediência civil como mecanismo de participação democrática e promoção de direitos fundamentais. Revista Eletrônica Direito e Política, Programa de Pós-Graduação Stricto Sensu em Ciência Jurídica da UNIVALI, Itajaí, v.13, n.1, 10 quadrimestre de 2018. Disponível em: www.univali.br/direitoepolitica - ISSN 1980-7791

conduta à sua concepção de integridade e correção, na mesma linha preconizada por Thoreau.

Quanto a este ponto, semelhante é a posição adotada por Walzer, para quem existe um dever de transgredir a lei considerada injusta, independentemente de as razões que levarem a ela serem de ordem moral, política ou religiosa. Para este filósofo, o dever de obediência é justificado pelos valores e pelos compromissos firmados pelos membros integrantes de um grupo ${ }^{34}$, o que implica o reconhecimento da possibilidade de violação de leis que cujos valores sejam conflitantes com os do grupo.

Vale lembrar que este dever de obediência, jamais tratado no plano jurídico, é originado, na visão do autor, "quando as obrigações assumidas em um grupo pequeno entram em conflito com obrigações adquiridas em um grupo maior que é geralmente o Estado ${ }^{3 \prime \prime}$. Nesse caso, haveria justificativas para que a ideia geral de compromisso com o cumprimento absoluto de obediência às leis fosse relativizada em prol de um compromisso moral em favor da reivindicação pública direcionada, geralmente, contra o Estado ${ }^{36}$.

Diferente é a posição de Garcia, que, de modo introdutório ao problema apresentado, defende que os totalitarismos criados por intermédio de governos autoritários e despóticos - acobertados por supostos regimes democráticos de governo -, da tecnocracia e de controladores de comunicação em massa, bem como a descaracterização e perda da legitimidade das representações políticas, tornariam o cidadão um ser extremamente vulnerável no exercício do poder político pelo Estado ${ }^{37}$.

\footnotetext{
34 WALZER, Michael. Das obrigações políticas. Ensaios sobre a desobediência, guerra e cidadania. Rio de Janeiro: Zahar, 1977, p. 10.

35 WALZER, Michael. Das obrigações políticas. Ensaios sobre a desobediência, guerra e cidadania. Rio de Janeiro: Zahar, 1977, p. 16-17.

36 WALZER, Michael. Das obrigações políticas. Ensaios sobre a desobediência, guerra e cidadania. Rio de Janeiro: Zahar, 1977, p. 23.

37 GARCIA, Maria. Desobediência civil: direito fundamental. 2. ed. São Paulo : Editora Revista dos Tribunais, 2004, p. 295-296.
} 
COSTA, Luís Otávio Monteiro; FABRIZ, Daury Cesar. Deveres fundamentais e soberania popular: a desobediência civil como mecanismo de participação democrática e promoção de direitos fundamentais. Revista Eletrônica Direito e Política, Programa de Pós-Graduação Stricto Sensu em Ciência Jurídica da UNIVALI, Itajaí, v.13, n.1, $1^{0}$ quadrimestre de 2018. Disponível em: www.univali.br/direitoepolitica - ISSN 1980-7791

O efeito imediato dessas questões seria a necessidade de se reestruturar o Estado, por um lado estabelecendo-se novas formas de participação do indivíduo-cidadão e de grupos de cidadãos, resguardando-se o império da lei e o dever geral de obediência que a acompanha, mas, por outro, possibilitando-se a execução de atos de desobediência civil, na medida em que se afiguraria como um direito fundamental de garantia do cidadão, assegurando-lhe, além da proteção à cidadania e da liberdade, a intervenção no processo político capitaneado pelo Estado ${ }^{38}$. De acordo com Garcia:

Considere-se em primeiro plano, que a dicção atual da norma contida no $\S 2^{\circ}$ do art. $5^{\circ}$, encerra um norteio para sua interpretação, aludindo às fontes dos direitos e garantias que pretende consagrar, diversamente dos textos anteriores. (...). A partir daí, inevitável se torna o atendimento ao comando constitucional e por este - pelo regime republicano de governo, o princípio democrático e o princípio da cidadania, elencados entre os princípios fundamentais do Estado Brasileiro (art. $1^{\circ}$ ), ao cidadão corresponde "um feixe de privilégios, decorrentes da condição da titularidade da coisa pública". (...) É dizer, o regime dos direitos fundamentais consagrado na Constituição Brasileira abrange, no seu sistema, a possibilidade de direitos fundamentais implícitos, decorrentes do regime e princípios adotados pela Constituição - dentre eles, o direito da desobediência civil ${ }^{39}$.

Logo, o seu posicionamento alude à consagração da desobediência civil como mais um direito integrante do rol de direitos fundamentais previstos na Constituição, ainda que a sua fundamentalidade seja implícita e esteja alicerçada em princípios fundantes de todo o texto constitucional brasileiro, como o são o democrático e o republicano.

Por fim, cogita-se a existência de um dever fundamental de desobediência civil em virtude da edição de leis ou medidas governamentais moralmente ou politicamente injustas, ou então, atentatórias a direitos. A relevância desta ponderação é, em parte, atribuída às questões principais que orbitam em torno da abordagem da desobediência civil, tais como os imperativos de moralidade e

38 GARCIA, Maria. Desobediência civil: direito fundamental. 2. ed. São Paulo: Editora Revista dos Tribunais, 2004, p. 296-297.

39 GARCIA, Maria. Desobediência civil: direito fundamental. 2. ed. São Paulo: Editora Revista dos Tribunais, 2004, p. 296-297. 
COSTA, Luís Otávio Monteiro; FABRIZ, Daury Cesar. Deveres fundamentais e soberania popular: a desobediência civil como mecanismo de participação democrática e promoção de direitos fundamentais. Revista Eletrônica Direito e Política, Programa de Pós-Graduação Stricto Sensu em Ciência Jurídica da UNIVALI, Itajaí, v.13, n.1, $1^{0}$ quadrimestre de 2018. Disponível em: www.univali.br/direitoepolitica - ISSN 1980-7791

justiça que devem nortear a produção legislativa e os atos executivos praticados pelos governos, a partir da outorga do poder pelo povo.

Nesse ponto, nota-se a coincidência de algumas premissas que sustentam a abordagem acerca da desobediência civil e dos deveres fundamentais, porquanto o entendimento destes últimos também aprecia as imposições de ordem moral, de ordem pública e de bem-estar de uma sociedade democrática ${ }^{40}$ que estão cingidas a esta categoria constitucional, ainda que sua aplicabilidade não se resuma às questões concernentes à resistência popular contra leis ou medidas governamentais tidas como injustas.

Esta coincidência de pressupostos permite que a abordagem conjunta parta de pontos em comum. No entanto, ressalta-se que, para além de uma aplicabilidade tão específica, a imposição de deveres fundamentais ${ }^{41}$ aos particulares compreende uma gama de possibilidades práticas mais amplas - se comparadas às possibilidades e finalidades da desobediência civil -, todas elas operantes no plano jurídico ${ }^{42}$ e destinadas à promoção de direitos fundamentais.

Essas possibilidades, sobretudo, dão ensejo à averiguação concreta de um potencial dever fundamental de desobediência civil na Constituição brasileira, conjecturando-se a existência de uma imposição jurídico-constitucional aos particulares, fundada no dever de solidariedade 43 , para fins de promoção de

40 NABAIS, José Casalta. O dever fundamental de pagar impostos: contributo para a compreensão constitucional do estado fiscal contemporâneo. Coimbra: Almedina, 2004, p. 31.

41 No presente estudo, os deveres fundamentais são entendidos como "[...] uma categoria jurídico-constitucional, fundada na solidariedade, que impõe condutas proporcionais àqueles submetidos a uma determinada ordem democrática, passíveis ou não de sanção, com a finalidade de promoção de direitos fundamentais", em consonância com o conceito elaborado de modo conjunto pelos membros do Grupo de Pesquisa "Estado, Democracia Constitucional e Direitos Fundamentais", coordenado pelos professores Adriano Sant'Anna Pedra e Daury Cesar Fabriz, do Programa de Pós-Graduação Stricto sensu em Direitos e Garantias Fundamentais da Faculdade de Direito de Vitória.

42 Sobre a juridicidade dos deveres fundamentais, vide Basso (BASSO, Joaquim. Notas sobre o regime jurídico dos deveres fundamentais no ordenamento jurídico brasileiro. Revista Direito UFMS, v. 1, n. 2, Campo Grande, MS, 2016, p. 91-92).

43 "Compreender o papel do dever de solidariedade, portanto, passa pela ideia de que o estudo do direito não pode ser afastado da análise da sociedade, de forma a permitir a individualização do papel e do fenômeno social. O direito tem como ponto de referência o homem na sua evolução psicofísica, 'existencial', que se torna história na sua relação com os outros homens" (DUQUE, Bruna Lyra; PEDRA, Adriano Sant'Ana. Os deveres fundamentais e a solidariedade nas relações privadas. Revista Direitos Fundamentais \& Democracia, v. 14, n. 14.1, p. 147-161, 2013). 
COSTA, Luís Otávio Monteiro; FABRIZ, Daury Cesar. Deveres fundamentais e soberania popular: a desobediência civil como mecanismo de participação democrática e promoção de direitos fundamentais. Revista Eletrônica Direito e Política, Programa de Pós-Graduação Stricto Sensu em Ciência Jurídica da UNIVALI, Itajaí, v.13, n.1, $1^{0}$ quadrimestre de 2018. Disponível em: www.univali.br/direitoepolitica - ISSN 1980-7791

direitos fundamentais consagrados no ordenamento jurídico pátrio, como, por exemplo, a cidadania e a liberdade, direitos estes historicamente relevantes para a sociedade brasileira.

Genericamente, pensar a existência de um dever fundamental exige considerar que o próprio ordenamento jurídico impõe às pessoas a busca por uma sociedade solidária (art. 30, I), ou, em outros termos, um dever de solidariedade, a partir do qual o bem comum seja almejado por todos e para todos.

Quanto a este dever de solidariedade inserido no conceito de dever fundamental, pode-se imaginar, por exemplo, que a exigência da prática de atos de desobediência civil - independentemente de sua modalidade ativa ou passiva, ou praticada por um indivíduo ou por grupos de cidadãos - pudesse hipoteticamente derrubar uma medida governamental segregadora, ou então limitadora de direitos fundamentais de defesa, como a liberdade de crença ou de expressão.

Nessas hipóteses, as medidas adotadas se materializariam mediante o exercício de um dever fundamental de desobediência civil, cuja fundamentalidade formal estaria pressuposta implicitamente nos princípios republicano e democrático (art, $1^{\circ}$ ) e cuja fundamentalidade material se atestaria na possibilidade real de promoção de direitos fundamentais previstos no art. $5^{\circ}$ da Constituição da República, fundados na proteção da dignidade da pessoa humana e das instituições democráticas.

Tais situações atenderiam, inclusive, a exigência descrita por Basso ${ }^{44}$, para quem os deveres fundamentais devem se prestar à garantia de aspectos estritamente associados à dignidade da pessoa humana, como, por exemplo, a satisfação de necessidades básicas do indivíduo ou que afetem a organização e funcionamento das instituições públicas, ou ao exercício dos direitos fundamentais bem como ao

\footnotetext{
44 BASSO, Joaquim. Notas sobre o regime jurídico dos deveres fundamentais no ordenamento jurídico brasileiro. Revista Direito UFMS, v. 1, n. 2, Campo Grande, MS, p. 87-108, 2016, p. 9192.
} 
COSTA, Luís Otávio Monteiro; FABRIZ, Daury Cesar. Deveres fundamentais e soberania popular: a desobediência civil como mecanismo de participação democrática e promoção de direitos fundamentais. Revista Eletrônica Direito e Política, Programa de Pós-Graduação Stricto Sensu em Ciência Jurídica da UNIVALI, Itajaí, v.13, n.1, $1^{0}$ quadrimestre de 2018. Disponível em: www.univali.br/direitoepolitica - ISSN 1980-7791

alcance de uma dimensão de utilidade geral em favor dos cidadãos detentores do direito subjetivo correlato ${ }^{45}$.

Por tudo isso, destaca-se a força do argumento tendente a reconhecer a existência de um dever fundamental de desobediência civil em casos em que leis ou medidas governamentais injustas afetem a dignidade da pessoa humana, a regular funcionamento das instituições democráticas ou outros direitos, normalmente relacionados a direitos de minorias.

Todavia, por outro lado, deve-se reconhecer a difícil aceitação e implementação deste suposto dever fundamental, uma vez que sua concretização está condicionada a infringência do ordenamento jurídico posto, o que, à luz da doutrina acerca dos deveres fundamentais, poderia ser interpretado como um sacrifício trivial ${ }^{46}$ por parte dos particulares, e, por isso, afastar qualquer tipo de exigência de atos de desobediência civil, mesmo diante de leis ou medidas governamentais classificadas como injustas.

\section{CONSIDERAÇÕES FINAIS}

A superação do Estado Absolutista e o subsequente advento do Estado Moderno introduziram um novo paradigma político-social, notadamente marcado pela ideia de que o poder não mais emanaria da vontade de um monarca supostamente predestinado, mas da vontade do povo, detentor do poder político, exercido em conformidade com os princípios democráticos da supremacia da vontade popular e da participação do povo no poder político.

\footnotetext{
45 Peces-Barba Martinez defende que "el ejercicio de um deber fundamental no reporta beneficios exclusivamente al titular del derecho subjetivo correlativo, cuando existe, sino que alcanza uma dimensión de utilidade general, beneficiando al conjunto de los ciudadanos y a su presentación jurídica, el Estado" (PECES-BARBA MARTÍNEZ, Gregório. Los deberes fundamentales. Doxa, n. 4, 1987, p. 336).

46 Tratando da compreensão sobre o que viria a ser o sacrifício trivial, Gonçalves e Fabriz, afirmam que "[...] o dever imposto a um indivíduo não pode ser exacerbado ou ir além das possibilidades dele, enquanto a solidariedade é apresentada como um sistema de freio à individualidade" (GONÇALVES, Luísa Cortat Simonetti e FABRIZ, Daury Cesar. Dever Fundamental: a construção de um conceito. In. DE MARCO, Christian Magnus e OUTROS. Direitos Fundamentais Civis: teoria geral e mecanismos de efetividade no Brasil e na Espanha. Tomo I. Joaçaba: Editora UNOESC, 2013).
} 
COSTA, Luís Otávio Monteiro; FABRIZ, Daury Cesar. Deveres fundamentais e soberania popular: a desobediência civil como mecanismo de participação democrática e promoção de direitos fundamentais. Revista Eletrônica Direito e Política, Programa de Pós-Graduação Stricto Sensu em Ciência Jurídica da UNIVALI, Itajaí, v.13, n.1, 10 quadrimestre de 2018. Disponível em: www.univali.br/direitoepolitica - ISSN 1980-7791

O exercício do poder tornou-se uma importante questão a ser delineada no âmbito democrático, privilegiando-se a forma da democracia representativa, em detrimento de outros tipos de democracia, uma vez que a prática direta do poder pelo povo, nos moldes da democracia direta exercitada na Antiguidade, tornarase materialmente impraticável frente à grande massa populacional.

Não obstante, com o transcorrer do tempo, este modelo desgastou-se em virtude da clara não correspondência entre a vontade popular e as manifestações e atos legislativos e executivos efetivamente concretizados. Esta situação escancarou o estado de falsa representatividade e o concomitante afastamento do cidadão das instâncias decisórias.

A partir das obras e dos referenciais utilizados como base, observou-se que, se por um lado é patente a crise de legitimidade dos representantes do povo, por outro está aberta a possibilidade de novas abordagens do fenômeno políticosocial, sobretudo ao possibilitar o debate acerca de outros meios que aproximem o cidadão das tensões políticas das quais foi ele afastado.

É nesse contexto que se identificou a relevância temática da desobediência civil, entendida, nesta pesquisa, como um mecanismo democrático que excepciona o dever geral de obediência às leis nos casos em que se entreveja a edição de leis ou medidas governamentais classificadas como injustas, por não representar os ideais de integridade do cidadão, ou então de justiça ou política da determinada comunidade política, na forma da teoria operacional da desobediência civil, formulada por Dworkin.

Além disso, à luz das obras de Garcia, Thoreau, Walzer e Dworkin, constatou-se a multiplicidade das abordagens acerca da desobediência civil no que diz respeito à sua caracterização como direito ou dever, tanto no plano moral, quanto no plano jurídico.

Enquanto Garcia vislumbra a existência de um direito fundamental de desobediência civil, com fundamento nos princípios democrático e republicano previstos na Constituição de 1988, os demais autores - com algumas divergências em alguns pontos - qualificam a desobediência civil, 
COSTA, Luís Otávio Monteiro; FABRIZ, Daury Cesar. Deveres fundamentais e soberania popular: a desobediência civil como mecanismo de participação democrática e promoção de direitos fundamentais. Revista Eletrônica Direito e Política, Programa de Pós-Graduação Stricto Sensu em Ciência Jurídica da UNIVALI, Itajaí, v.13, n.1, $1^{0}$ quadrimestre de 2018. Disponível em: www.univali.br/direitoepolitica - ISSN 1980-7791

respectivamente, como um dever moral do indivíduo de desobedecer: em razão de uma objeção de consciência; em virtude de um compromisso firmado com o grupo de que faz parte; em função de sua compreensão pessoal de integridade, ou da implementação de políticas que prejudiquem injustamente uma minoria, ou, ainda, da implementação de políticas que coloquem em risco a totalidade de determinada comunidade política.

No mais, constatou-se um fundamento em favor da existência de um dever fundamental de desobediência civil em situações em que a lei ou medida governamental considerada injusta que reprimam direitos fixados no ordenamento jurídico.

Nessa hipótese, entende-se que a efetivação de atos de desobediência civil por particulares tem o condão de promover direitos fundamentais estritamente ligados ao exercício da soberania popular expressada por meio da cidadania, à garantia da dignidade da pessoa humana, assim como à proteção das instituições e valores democráticos.

Por outro lado, identificou-se a possibilidade da existência de argumentos que venham a rechaçar a exigência de atos de desobediência civil, em virtude da possível configuração de um sacrifício trivial por parte dos particulares, considerando-se a suposta exigência de violação do ordenamento jurídico posto, ainda que diante de leis ou medidas governamentais rotuladas como injustas.

\section{REFERÊNCIAS DAS FONTES CITADAS}

BASSO, Joaquim. Notas sobre o regime jurídico dos deveres fundamentais no ordenamento jurídico brasileiro. Revista Direito UFMS, v. 1, n. 2, Campo Grande, MS, p. 87-108, 2016.

BOBBIO, Norberto. O futuro da democracia. 9a. Ed. Trad. Marco Aurélio Nogueira. São Paulo: Paz e Terra, 2000.

BONAVIDES, Paulo. Ciência Política. $10^{\circ}$ edição, $9^{a}$ tiragem Editora Malheiros, 2000.

DALLARI, Dalmo de Abreu. Elementos de teoria geral do Estado. 27. ed. São Paulo: Saraiva, 2007. 
COSTA, Luís Otávio Monteiro; FABRIZ, Daury Cesar. Deveres fundamentais e soberania popular: a desobediência civil como mecanismo de participação democrática e promoção de direitos fundamentais. Revista Eletrônica Direito e Política, Programa de Pós-Graduação Stricto Sensu em Ciência Jurídica da UNIVALI, Itajaí, v.13, n.1, 10 quadrimestre de 2018. Disponível em: www.univali.br/direitoepolitica - ISSN 1980-7791

DWORKIN, Ronald. Uma questão de princípio. Tradução Luís Carlos Borges. São Paulo: Martins Fontes, 2000.

DUQUE, Bruna Lyra; PEDRA, Adriano Sant'Ana. Os deveres fundamentais e a solidariedade nas relações privadas. Revista Direitos Fundamentais \& Democracia, v. 14, n. 14.1, p. 147-161, 2013.

GARCIA, Maria. Desobediência civil: direito fundamental. 2. ed. São Paulo : Editora Revista dos Tribunais, 2004

GONÇALVES, Luísa Cortat Simonetti e FABRIZ, Daury Cesar. Dever Fundamental: a construção de um conceito. In. DE MARCO, Christian Magnus e OUTROS. Direitos Fundamentais Civis: teoria geral e mecanismos de efetividade no Brasil e na Espanha. Tomo I. Joaçaba: Editora UNOESC, 2013.

LUCAS, Doglas Cesar. A desobediência civil na teoria jurídica de Ronald Dworkin. Revista de Direitos Fundamentais e Democracia. Curitiba, v. 16, n. 16, p. 116-129, julho/dezembro, 2014.

LUCAS, Javier de. Una consecuencia de la tesis de los derechos: la desobediencia civil segun R. Dworkin. In: Doxa n² 2, 1985.

NABAIS, José Casalta. O dever fundamental de pagar impostos: contributo para a compreensão constitucional do estado fiscal contemporâneo. Coimbra: Almedina, 2004.

PECES-BARBA MARTÍNEZ, Gregório. Los deberes fundamentales. Doxa, n. 4, p. 329-341, 1987.

PEDRA, Adriano Sant'Ana. A Constituição viva: poder constituinte permanente e cláusulas pétreas na democracia participativa. Rio de Janeiro: Lumen Juris, 2014.

THOREAU, Henry David. A desobediência civil. Tradução José Geraldo Couto. São Paulo: Penguin Classics Companhia das Letras, 2012.

WALZER, Michael. Das obrigações políticas. Ensaios sobre a desobediência, guerra e cidadania. Rio de Janeiro: Zahar, 1977.

WEBER, Thadeu. Ética, direitos fundamentais e obediência à Constituição. Veritas (Porto Alegre), v. 51, n. 1, 2007.

ZANETI JÚNIOR, Hermes. A constitucionalização do processo. 2. ed. São Paulo: Atlas, 2014.

Submetido em: 30/11/2017

Aprovado em: 06/03/2018 